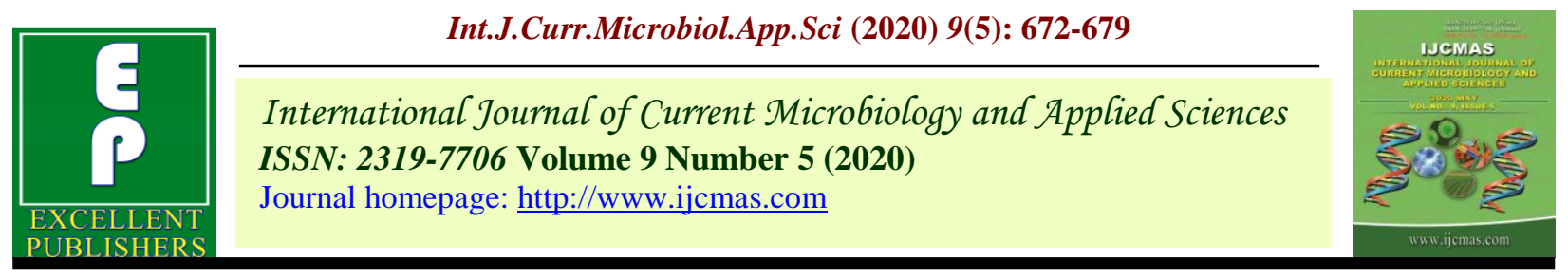

Review Article

https://doi.org/10.20546/ijcmas.2020.905.074

\title{
Pruning for Winter Crop Production in High Density Guava Plantations - A Review
}

\author{
Uday Raj Patial*, Sanjeev K Banyal and Ajay Banyal and Shiv Kumar \\ Department of Fruit Science, College of Horticulture \& Forestry, Dr. YS Parmar University \\ of Horticulture and Forestry, Neri, Hamirpur, H.P. 171001, India \\ *Corresponding author
}

\begin{tabular}{|l|}
\hline Ke y w o r d s \\
Winter crop \\
production, High \\
density, Guava \\
plantayion
\end{tabular}

\section{A B S T R A C T}

High density meadow orcharding and crop regulation has made an important breakthrough for optimization of the guava fruit production. The land rates are hiking day by day and there is need for early returns from the invested capital, so it became a worldwide trend to plant trees on a high planting density and to manipulate tree architecture by canopy management to control growth pattern, shape of the plant and increase the fruit production. In guava, three distinct flowering seasons were identified in different parts of India. Flowering occurs on the current season's growth, even though the crop is available around the year. The rainy crop is of inferior quality, infested with fruit flies and do not keep well, whereas the winter crop produces a better fruit quality, fetch a premium price and has a long shelf life. Hence rainy season crop is regulated to next winter season by pruning. Pruning at different timings have shown different effects on the growth, flowering and yield parameters of the crop. It's essential to standardize the pruning time in order to get crop with higher returns.

\section{Introduction}

Guava (Psidium guajava L.) commonly known as "Poor Man's Apple" or "Apple of Tropics" is one of the major fruit crop of Subtropical and tropical climatic regions. The center of origin of the crop is believed to be Tropical America, extending from Mexico to Peru. In the early 17th century the Portuguese introduced this plant to India (Singh, 1995) and today India is one of the major producers of Guava. Guava belongs to the family 'Myrtaceae' and is having chromosome number $2 n=22$. The

Genus Psidium consists of more than 150 species but only Psidium guajava is commercially exploited. The common guava is diploid but many of natural and artificial triploids $2 n=33$ and aneuploids do exist. 


\section{Present status}

Among guava producing countries, India ranks $1^{\text {st }}$ in area and production followed by China and Thailand. The highest productivity of 15.8 tones/ha had been recorded in Brazil. In India, guava is the $5^{\text {th }}$ most important fruit in production after Banana, Mango, Citrus and Papaya. It occupies an area of 2.61 lac hectares with annual production of 36.4 lacs MT and productivity of $13.94 \mathrm{MT} / \mathrm{ha}$ in India. Though it is grown successfully all over the country but Uttar Pradesh, Bihar, Madhya Pradesh and Maharashtra are leading producers. Among Indian states Uttar Pradesh ranks $1^{\text {st }}$ both in area (49 thousand ha) and production (9.19 lacs MT) alone while Punjab accounts for the highest productivity 22.46 MT/ha. (Anonymous, 2017)

\section{Composition}

Guava is an excellent source of ascorbic acid, dietry fibre, pectin and minerals. The composition of guava fruits varies widely with cultivars, stage of maturity and season. The predominant sugars are fructose $(59 \%)$, glucose $(36 \%)$ and sucrose (5\%) (Mahor et $a l ., 2014)$. Fructose is the principal sugar in the green ripe fruits while fully ripe fruits contain higher amount of sucrose.

\section{Importance of pruning}

Pruning in guava is pre-requisite for the better growth and yield of fruits because it bears on current season growth and flowers appear in the axils of new leaves. In Guava there are three distinct flowering seasons: Spring (Ambebahar), Rainy (Mrigbahar) and autumn (Hasthabahar) with the corresponding rainy, winter and spring harvesting cycles. After 7-8 years guava plants owe to excess vegetative growth and intermingling of the branches on the lower half of the tree canopy resulting in unfruitfulness, as the fruitful bud becomes blind and there is a decline in the yield with sub-optimal fruit quality. Pruning on bearing trees leads to the formation of new shoots, avoid overcrowding of branches, removal of criss-cross branches, diseased branches as well as water sprouts and root suckers. Hence pruning is considered as an important practice especially in meadow orchards where restriction of vegetative growth is essential for maintenance of plant canopy at a desirable height influencing the vigor, productivity and quality of the fruits to encourage new shoot emergence after harvest. Several workers have reported increase in vegetative and qualitative attributes of guava as a result of pruning at different periods. Therefore pruning levels and time of pruning in guava under high density conditions has achieved a greater importance.

\section{Vegetative growth parameters}

\section{Plant height}

Lian (2019) pruned the plants of L-49 guava at different times (mid-April, mid-May, midJune) and recorded the plant height to be maximum with mid-April pruning. Similar observations were recorded when Singh (2005) carried rejuvenation pruning on fifteen years old L-49 guava plants from April to June. Likewise, Sah (2017), Rajwant and Dhaliwal (2001) reported maximum increase in the plant height with pruning in the month of April.

Nikumbhe (2017) monitored the effect of the different times of pruning (May, June, July, August and September) and observed maximum increase in the plant height in May pruned plants while minimum with pruning in August. These results were in line with the findings of Pandey (2013) and Kindo (2005) who reported maximum increase with May pruning. 
However Kumar and Rattanpal (2010) reported no significant effect of the pruning time on the plant height and found it maximum in unpruned plants. These results were supported by the findings of Lal (1992) and Anez (1998) where unpruned plants were recorded with maximum increase in plant height

\section{Shoot length}

When ten years old plants of Lalit guava planted at as spacing of $6 \times 6 \mathrm{~m}$ were pruned at different times Meena (2016) recorded maximum increase $(24.32 \mathrm{~cm})$ in the shoot length in May pruned plants while minimum increase $(10.88 \mathrm{~cm})$ in control followed by pruning in June $(17.12 \mathrm{~cm})$. The results of this experiment were in line with the findings of Dhliwal (2004), Anez (1998) and Mohammad (2002) who reported maximum increase in the shoot length with pruning in May.

Lian (2019) revealed that the shoot length had been significantly influenced by the difference in the time of pruning. The highest shoot length $(23.67 \mathrm{~cm})$ was recorded in midMay pruned plants which were at par with mid-April pruning $(23.11 \mathrm{~cm})$ and lowest $(20.89 \mathrm{~cm})$ in mid-June pruned plants.

Contrary to the above findingsNikumbhe(2017) reported highest increase in the shoot length in unpruned plants $(120 \mathrm{~cm})$ followed by pruning in May $(86.50 \mathrm{~cm})$ while lowest in the September pruned plants $(67.50 \mathrm{~cm})$.

\section{Plant spread}

Sah (2017) recorded the highest increase in plant spread with three-leaf pair pruning in comparison to full-shoot pruning during June, as the net photosynthetic area gets reduced for some time with full shoot pruning resulting in reduced plant spread. Likewise, Singh (2007) studied the response of guava (cv. Allahabad Safeda) plants to different rejuvenation periods. The plants were pruned leaving four scaffold branches per leaf from April to June. The plant spread was observed to be significantly affected with different rejuvenation periods. The plant spread was lowest in May and highest in June pruned plants.

However, Meena (2016) recorded highest increase in the plant spread with pruning in May, when 10 years old plants of Lalit guava were subjected to pruning at different timings (April, May and June). Similar results were obtained by Lian (2019) on L-49 guava plants.

\section{Flowering parameters}

\section{Time of flowering}

It is a general tendency to grow new shoots after pruning as soon as possible, but, the response was different as per the time and severity of pruning. Meena (2016) reported that the control plants flowered very late (51.33 days) while pruning treatments triggered early blooming. Plants pruned at 45 $\mathrm{cm}$ during April flowered at an interval of 32.67 days after pruning, while over 45 days in other pruning treatments. Dhaliwal and Kaur (2003) observed an early flowering with an increase in the severity of pruning, while delayed pruning resulted in late flowering, reduction in flowering age and flowering percentage. Basu (2007) studied the effect of different times of pruning on the cropping behavior of 11 years old L-49 guava. Pruning in the month of April resulted in early flowering (i.e. 51 days after pruning) while delayed flowering when pruned in July (66 days after pruning).

However, Singh (2001) subjected 15 years old plants of Allahabad Safeda and Sardar guava 
to pruning at varying timings and observed that pruning in May resulted in flowering from July- September while, February pruned plants flowered during April.

\section{Fruit set}

The interaction effect of the intensity and time of pruning was studied by Ali (2014) on 10 years old guava plants. The fruit set was recorded to be maximum during both the rainy $(73 \%)$ and winter $(75 \%)$ seasons with pruning of $10 \mathrm{~cm}$ of shoots in May. Likewise Lian (2019) observed a sudden decrease in percent fruit set with increase in the intensity of pruning. The maximum fruit set $(83.33 \%)$ was reported by pruning of $50 \%$ of the shoot length in mid-May while lowest with pruning of $75 \%$ shoot length during mid- June. The reproductive growth was observed to be increasing with light pruning while severe pruning favors vegetative growth.

Contrary to the above findings Brar (2007) observed the fruit set to be positively correlated with the increase in the severity of pruning during both the rainy and winter seasons, when eleven years old Sardar guava plants were pruned in May at three different pruning intensities $(15,30$ and $45 \mathrm{~cm})$. The results of this observation were parallel to the findings of Singh (2011) and Lotter (1990) who reported an increment in the percent fruit set with the increase in the severity of pruning.

However, Boora et al., (2016) observed that reduction in the fruit set during the rainy season crop is necessary to improve the fruit set during the winter crop.

\section{Fruit yield}

After the pruning of plants in MayBagchi et al., (2008) observed an increase in the concentration of proline, peroxidase, polyphenol oxidase, tryptophan and reduction of phenolics in the different plant parts, leading to increased flowering and fruiting during the winters and contributing higher yield per plant.

Das (2018) investigated the effect of the different time of pruning on both the rainy and winter season crops of guava and obtained maximum yield during the rainy season with pruning in the month of October while pruning in the month of May yielded highest crop in the winter season. Similar results of fruit yield were obtained by Dubey et al., (2002), Gopi Krishna (1981), Joshi (2014) and Meena (2005) when plants were pruned in the month of May for the production of winter season crop.

However, Adhikari (2015) reported a significant fall in the fruit yield during the winter season with the enhancement of pruing severity. While, highest yield in the winter season crop was obtained with mild pruning of the guava plants in early May. Likewise Sah (2017) and Prabhakar (2016) observed similar trend for fruit yield.

\section{Fruit quality}

\section{Fruit size}

The fruit size was observed to be significantly affected with the time of pruning when, Sah (2017) subjected seven years old plants of guava growing under meadow orcharding to half shoot pruning at different timings. The fruit length was recorded maximum in the plants pruned during June while, maximum fruit width in April pruned plants.

Severe pruning was reported to have a marked effect on the fruit size. Adhikari (2015) reported that the maximum size was obtained the fruit produced on the plants pruned at 30 $\mathrm{cm}$ level of pruning during mid-May. 
Likewise, Basu (2007) recorded maximum fruit size in the fruits produced on the plants pruned in May.

\section{Fruit weight}

As a result of pruning the number and area of leaves increases causing an increase in the number of photosynthates and lead to increase in the fruit weight during the winter season crop (Singh et al., 2001). The fruit weight was observed to be increasing with the enhancement of pruning severity and delay in the time of pruning Adhikari (2015). Pruning at the level of $30 \mathrm{~cm}$ in early-May produced heavier fruits in the rainy season while during winters heavier fruit were produced with pruning at $30 \mathrm{~cm}$ level in mid-May. Similar trend was observed by Basu (2007) when eleven years old plants of Sardar guava were pruned keeping 4 scaffold branches in the May.

However, Das (2018) reported that therewas no significant effect of the pruning treatments on the fruit weight of the rainy and summer season crops for three continuous years except for the winter season crop. The plants pruned in May yielded fruits with maximum weight during the winters in all the three years.

\section{Biochemical parameters}

The fruits produced in the winter season were found to be rich in biochemical aspects than rainy season crop, as the higher crop loads lead to the drainage of food reserves hiking the competition for food reserve among the fruits. Aswathy(2017) subjected guava plants to pruning at different timings and observed that fruits produced in winter were superior in quality than the rainy season crop. The plants pruned in May produced fruits with highest TSS $\left(11.11^{\circ} \mathrm{B}\right)$ and acidity $(0.28 \%)$ while total sugars and ascorbic acid content was recorded maximum in plants pruned during mid-April. These results were parallel to the findings of Ali (2014), Sahar et al., (2014), Sah (2017) and Shiranal (2018).

A significant increase in the TSS and acidity was recorded by Parmar (2019) with increase in the severity of pruning during May while, an inverse trend in the total sugars and Ascorbic acid content. The pruning at $50 \%$ level in May produced fruits with TSS $\left(11.46^{\circ} \mathrm{B}\right)$, acidity $(0.79 \%)$, Ascorbic acid $(177.2 \mathrm{mg} / 100 \mathrm{~g})$ and total sugars $(7.37 \%)$ while fruits from $25 \%$ pruned plants were recorded with TSS $\left(11.08^{\circ} \mathrm{B}\right)$, acidity $(0.76$ $\%)$, Ascorbic acid (180.2 mg/100 g) and total sugars $(7.84 \%)$. These results were in line to the findings of Balamohan (2019), Kumar (2010), Basu (2007), Lal (2002), Kindo (2005) and Sah (2013). This increase in the sugars and ascorbic acid might be due to the impact of high temperatures during flowering, fruit formation and maturation, leading to the degradation of polysaccharides into simple sugars by various metabolic processes, conversion of organic acids into the sugars and the reduction of moisture content as suggested by Lakpathi et al., (2013).

\section{Time of maturity}

Singh (2001) observed that the fruits on the plants pruned in the May start getting mature by the mid-November and the first harvest was obtained on the last week of November. The harvesting spam was concentrated from November to January. However fruits on the plants pruned in the June matured in the end of December. Likewise, Singh et al., (2015) recorded fruit maturity 136 days after the pruning in the month of May.

Tiwari (2018) subjected the plants of Allahabad Safeda to pruning of $50 \%$ of shoot in the August then harvesting was done in January-February. Similarly when thirteen 
years old plants of guava were subjected to pruning at $1 / 3^{\text {rd }}$ length in the month of April, the fruits got matured by the first October and harvesting was continued till November.

On the basis of the above findings it can be concluded that selection of the optimum time of pruning is a major operation as whole the cropping, flowering, fruit quality and harvesting pattern can be manipulated by choosing the right time of pruning according to the climatic conditions and adaptation of the crop to the climatic conditions.

\section{References}

Adhikari, S., and Kandel, T. P., 2015. Effect of time and level of pruning on vegetative growth, flowering, yield, and quality of guava. Inter J Fruit Sci 15: 290-301.

Ali, F., 2014. Effect of pruning on yield and Fruit Quality of Guava Trees. IOSR Journal of Agriculture and Veterinary Science (IOSR-JAVS) e-ISSN: 23192380, p-ISSN: 2319-2372. Volume 7, Issue 12 Ver. IV, PP 41-44.

Anez, Q. M., 1998. Effect of pruning on flowering and fruiting in guava (Psidium guajava L.) RevistaUnillez de ciencia Technologia, Production Agricola 16: 91-106.

Anonymous,. 2017-18. Area and Production of Horticulture crops: All India, National Horticulture Board. (12:15 PM, 14th June 2019).

Aswathy, S., 2017. Effect of pruning intensities on yield of guava (Psidium guajava L.) cv. LUCKNOW 49. Asian Journal of Horticulture, 12(2), 202205.

Bagchi, T. B., Sukul, P., and Ghosh, B., 2008. Biochemical changes during offseason flowering in guava (Psidium guajava L.) induced by bending and pruning. J Trop Agr 46: 64-66
Balamohan, T. N., 2019. Effect of pruning levels and growth regulator application on guava (Psidium guajava L.) cv. Lucknow - 49 for high yield and quality. Annals of Plant Sciences 8.3: 3510-3513

Basu, J., Das, B., Sarkar, S., Mandal, K. K., Banik, B, C., Kundu, S., Hasan, M. A., Jha, S., and Ray, S. K., 2007. Studies on the response of pruning for rejuvenation of old guava orchard. ActaHort 735: 303-09.

Boora, R. S., Singh, H., and Singh, G. 2016. Effect of pruning on crop regulation of guava cv. Allahabad Safeda. Haryana J. Hort. Sci.; 36(3 and 4): 270.

Brar, J. S., Thakur, A., and Arora, N. K., 2007. Effect of pruning intensity on fruit yield and quality of guava (Psidiumguajava L.) cv. Sardar. Haryana J. Hort. Sci.; 36(1/2): 65-66.

Das, Bikash., Mehta, Sarita., Singh, S. K., Mali, Santosh., Dhakar, M. K., and Singh, A. K., 2018. Pruning effects on Sardar guava planted in ultra-high density orcharding under different rainfall scenarios. Indian J. Hort. 75(4): 583-590

Dhaliwal, G. S., and Kaur, R., 2003. Effect of time and pruning intensity on age of bearing shoot and fruit quality of "Sardar" guava. Haryana Journal of Horticultural Sciences 32: 21-24.

Dhaliwal, G. S., and Singh, G., 2004. Effect of different pruning levels on vegetative growth, flowering and fruiting in sardar guava. Haryana $J$ HortSci 33: 175-77.

Dubey, A. K., Singh, D. B., Barche, S., Singh, A., and Dalal, M., 2002.Deblossming in summer season flowering in guava. Indian Hort 4: 35-36

Gopikrishna. N. S.,1981. Studies on the effect of pruning on vegetative growth, flowering and fruiting in Sardar guava (Psidium guavjava L.). Karnataka J 
AgriSci 10 (1): 93-97.

Joshi, P., Lal, S., Nautiyal, P., and Pal, M., 2014. Response of plant spacing and pruning intensity on yield contributing characteristics of guava cv. Pant Prabhat. Journal of Hill Agriculture, 5(2), 163-167.

Kindo, P., 2005. Studies on various methods of crop regulation in guava (Psidium guajava L.) cv. Pant Prabhat. M.Sc. Thesis, G. B. Pant University of Agriculture and Technology, Pantnagar, U. S. Nagar, India.

Kumar, Y., Rattanpal, H. S. 2010. Effect of pruning in guava planted at different spacings under Punjab conditions. Indian J. Hort.; 67:115-119.

Lakpathi, I. G., Rajkumar, M., and Chandrasekhar, R., 2013. Effect of pruning intensities and fruit load on growth, yield and quality of guava cv. Allahabad Safeda under high density planting. Int. J. Curr. Res., 5 (12): 4083-4090.

Lal, S., 1992. Response of guava (Psidium guajava L.) cv. Sardar to spacing and pruning intensities. Ph. D. Dissertation. G B Pant University of Agriculture and Technology, Pantnagar, U.S. Nagar, India.

Lian, H. N., Singh, B., Senjam, B. D.,\&Ramjan, M., 2019. Effect of Shoot Pruning on Growth and Yield of Guava (Psidium guajava L.) cv. L-49 under Foothills of Arunachal Pradesh. Int. J. Curr. Microbiol. App. Sci, 8(3), 2020-2027.

Lotter, J. De. V., and Lotter, De. V. J., 1990. Vegetative and reproductive habit of guava in relation to pruning methods. Acta Horticulture 275: 229-37.

Mahor, M. K., Tiwari, R., and Baghel, B. S., 2014. Physico chemical characteristics of different varieties of guava in Malva Plateau of Madhya Pradesh. Agric. Sci. Digest. 32(2): 144.
Meena, K. R., Maji, S., Kumar, S. and Verma, S., 2016. Influence of shoot pruning for crop regulation and improving fruit set of guava. AktaAgrosia, 11(2): 1355-1359, 2016.

Meena, R. P., Mohammed, S., and Lakhawat, S. S., 2005. Effect of foliar application of urea and zinc sulphate on fruit quality and yield of pruned guava trees (Psidium guajava L.) cv. 'Sardar' under high density planting system. $J$. Hort. Sci., 11 (2): 90-93.

Nikumbhe, P. H., Musmade, A. M.,\&Patil, R. S., 2017. Response of pruning time on vegetative growth and yield of Guava (Psidium guajava L.) selections. AktaAgrosia, 22(2), 8-13..

Pandey, S., 2013. Studies on the effect of different dates of pruning on growth yield and fruit quality of guava under High Density planting cv. Allahabad Safeda. M.Sc. thesis, Jawaharlal Nehru KrishiVishwaVidyalaya, Jabalpur, India.

Parmar, A. B., Patel, H. C., Patel, D. D., and Parmar, J. R., 2019. Effect of pruning and plant growth regulators on fruit quality of guava (Psidium guajava L.) cv. Allahabad Safeda. International Journal of Chemical Studies; 7(4): 858-862

Prabhakar, J., Naytiyal, P., Lal, S., and Pal, M., 2016. Response of plant spacing and pruning intensity on yield contributing characteristics of guava cv. Pant Prabhat. J. Hill. Agri., 5 (2): 163-167.

Rajwant, K., Dhaliwal, G. S.,2001. Effect of time and pruning intensity on tree canopy volume, girth and plant height in Sardar guava. Haryana J. Hort. Sci.; 30:154-156

Sah, H., Lal, S., and Negi, S. S., 2017. Effect of pruning on growth, flowering and yield in high density planting of guava. Int. J. Pure App. Biosci, 5(1), 
285-292.

Sah, H., 2013. Response of time of shoot pruning in meadow orchard of guava (Psidium guajava L.) cv. Pant Prabhat (Doctoral dissertation, Ph. D. (Hort.) Thesis).

Sahar, F., and Abdel-Hameed, A. A., 2014. Effect of pruning on yield and fruit quality of guava trees. J Agric Vet Sci 7: 41-44.

Shiranal, R., Patil, S. N., Naik, R., Goudappanavar, B. and Hachcholli, A., 2016. Effect of Pruning Intensities on Yield and Economics of Guava cv. Sardar under different Spacing and Season. Indian Horticulture Journal, 6(2), 187-189.

Singh, G., and Chanana, Y. R., 2005. Influence of pruning intensity and pruning frequency on vegetative and reproductive attributes in guava cv. L49. 1st Int. Guava Symp., CISH, Lucknow., pp. 52.

Singh, G., Singh, A. K., Rajan, S., 2001. Influence of pruning date on fruit yield of guava (Psidium guajava L.) under subtropics. J. Appl. Hort.; 3(1): 37-40.

Singh, G., 2011. Influence of pruning intensity and pruning frequency on reproductive attributes and leaf $\mathrm{C} / \mathrm{N}$ ratio in Sardar guava. Haryana $J$. Hortic. Sci.; 40(3\&4):140-144.

Singh, P., and Jain, V., 2007. Fruit growth attributes of guava (Psidium guajava L.) cv. Allahabad Safeda under agroclimatic conditions of Chhattisgarh. ActaHorticulturae 735: 335-8.

Singh, V. K., Ravishankar, H., Singh, A., and Soni, M. K., 2015. Pruning in guava (Psidium guajava) and appraisal of consequent flowering phenology using modified BBCH scale, Indian Journal of Agricultural Sciences 85 (11): 1472-6

Singh, S. P., 1995. Commercial fruits. New Delhi, Kalyani publisher, p. 148.

Tiwari, R. B., Tiwari, J. P., Lal, S., 2018. Effect of shoot pruning, NAA and urea on cropping pattern of guava. Indian J. Hort.; 49(4):305-308.

\section{How to cite this article:}

Uday Raj Patial, Sanjeev K Banyal and Ajay Banyal and Shiv Kumar. 2020. Pruning for Winter Crop Production in High Density Guava Plantations - A Review. Int.J.Curr.Microbiol.App.Sci. 9(05): 672-679. doi: https://doi.org/10.20546/ijcmas.2020.905.074 